The Japanese Journal of Experimental

Social Psychology. 1988, Vol. 28, No. 1, 35-46

〔原 著]

\author{
緊急異常事態発生時の対処行動に及ぼす \\ 平常時リーダーシップ行動の効果1)2) \\ 大阪大学 ${ }^{31}$ \\ 矢守克也 \\ 奈良大学 \\ 三隅二不二
}

問

題

本研究は, 平常事態におけるリーダーのリーダーシッ プ行動が, 平常事態における部下の作業量（以下, 「平 常事態パフォーマンス」と略称) に及ぼす効果と, 緊急 異常事態発生時に打ける部下の対処行動（以下，「異常 事態対処行動」と略称）に及ぼす効果を実験的に検討し たものである。

\section{平常事態パフォーマンスと異常事態対処行動}

まず, 本研究で比較検討した 2 つの従属変数（「平常 事態パフォーマンス」と「異常事態対処行動」）につい て述べる。

「平常事態パフォーマンス」とは, リーダーがフォロ ワーに遂行を命じた作業の作業量である。リーダーシッ プの効果性に関する従来の実験的研究で主に検討されて きた従属変数, 例えば, IBM カードの穿孔数をできる だけ早く, 正確に数えるといった単純作業課題（三隅・ 白樫, 1964), 逆アルファベット文字の模写を行なうと いった学習課題（三隅・佐藤，1968）, TAT 図版を基に できるだけ独創的な物語を作成するといった企画立案型 の課題 (Fiedler \& Chemers, 1977) 等におけるフォロ ワーのパフォーマンスはすべて「平常事態パフォーマン ス」である。

これに対し, 本研究における「異常事態対処行動」と は, 各集団成員がリーダーから直接与えられた作業とは 直接的な関係をもたないが, 集団全体の効果性 (effectiveness）に対してはネガティブな影響を及ぼしかねな いような突発的異常事態に対する対処行動のことである。 具体的には, 工場などにおいて, 自分の担当外の機器に

1 ) 本研究は, 昭和61～62年度文部省科学研究費総合研究（A）(「危機状況におけるリーダーシップと避難行動に 関する研究」(課題番号：61301013), 研究代表者：三隅二不二）によって実施されたあのであるが, 本研究の 実施並びに結果のまとめは主として矢守克也によって行われたものである。

2 ) 実験の実施にあたっては, 大阪大学人間科学部の清水梊也氏 (現三菱雷機勤務), 土佐裕子氏 (現月本電気勤 務), 中山貴子氏 (現シャープ勤務) の協力を得た。記して感謝の意を表する。

3 ) 現所属 (財)集団力学研究所

異常を示す警告ランプが点灯するのを発見した作業員が, 担当者に知らせる，上司に報告するといった行動をとっ たとすれば，それが「異常事態対処行動」に相当する。

したがって, 本研究で検討する「異常事態対処行動」 は,リーダーによって命ぜられた作業を効果的に遂行す るだけでなく，所与の作業とは異なる側面に対してあ状 況の変化に適応し, 柔軟性のある行動をとれるかどうか という点に関わる。従来の組織心理学的研究の多くは, 組織有効性の主要な下位次元の一つとして,「生産性 (productivity)」とは別に「柔軟性・適応性 (flexibility /adaptation)」を指摘している (Steers, 1975) が, 本 研究に打ける「異常事態対処行動」はこの次元と関連す るあのである。

さて, 本研究における「異常事態対処行動」に関して 次の 2 点が指摘される。第 1 は, 本研究に打ける「異常 事態対処行動」は, 明らかに緊急異常事態が発生した後 のフォロワーの行動を指すのではなく，むしろ，あいま いな異常の前兆が生じているような状況下，すなわち， 平常事態から異常事態への転換点におけるフォロワーの 柔軟な対処行動を指すという点である。その意味では, 電気ショック予告によって模擬的な緊急恐怖状況を構成 し, フォロワーの迷路脱出行動に及ぼすリーダーシップ の効果性を検討した釘原・三隅（1984）の実験など, 実 験開始当初から被験者を緊急異常事態下に打き, 避難行 動やパニック行動を検討した諸研究における従属変数は, 被験者がおかれた状況自体は緊急性を内包するあのであ るが, 本研究における「異常事態対処行動」とは区別さ れる。

さて,こうした「異常事態対処行動」に関しては, 
French (1941) の研究や Latane \& Darley (1968)の 研究などが行なわれてきた。French は問題解決に従事 する集団に扔いて突発的に緊急異常事態 (ビル火災に模 した煙が作業室に流入する）を生起させ，それに対する 対処行動について, 組織化された集団と未組織的な集団 とを比較検討した。また, Latane と Darley はインタ ビュ一調查の参考にするという名目の調查票に被験者が 回答している最中に, 調查室に煙を流入させるという緊 急異常事態を生起させ, それに対する被験者の対応を検 討した。すなわち, 検討された従属变数は平常時に被験 者または被験者集団に予め与えられていた課題ではなく, 突発的に生じた緊急異常事態に抢ける対処行動であった。 この点で, これらの研究で吟味された従属変数は本研究 の「異常事態対処行動」之同じ範疇に属する。

このように Frenchや Latane と Darley は本研究に おりる「異常事態対処行動」に相当する行動を検討して いるが，乙れらの研究を除けば，乙れまで「異常事態対 処行動」はほとんど吟味されておらず, 特にリーダーシ ップの効果に関して検討した研究で「異常事態対処行 動」に相当する従属変数を吟味したあのは皆無である。 しかし, 当該集団の効果性を総合的に検討するためには 「平常事態パフォーマンス」だけでなく，「異常事態対 処行動」屯考慮にいれる必要があると思われる。特に, 突発事故や災害の防止という観点からは, むしろ後者の 方がより実践的重要性をあつものと考えられよう。

本研究の「異常事態対処行動」に関する第 2 の特徵は, 緊急異常事態発生時のリーダーシップではなく, 先行条 件としての平常時に打けるリーダーシップが「異常事態 対処行動」に及ぼす効果を吟味する点である。従来は, 平常事態におけるリーダーシップが, 同じ平常事態にお ける何らかの従属変数 (例えば, 単純課題, 学習課題, 企画立案型課題に打けるフォロワーのパフォーマンス）に 及ぼす効果に関する研究（三隅・白樫，1964など）上， 緊急異常事態に括けるリーダーシップが同じ緊急異常事 態に打ける何らかの従属変数（例えば, フォロワーの迷 路脱出行動, 避難行動) に及ぼす効果に関する研究（釘 原・三隅，1984など）とがまったく独立に行われてきた。 言いかえれば, 平常事態のリーダーシップと緊急異常事 態のフォロワーの行動を関連づけて検討した研究はなか ったのである。本研究では, 従来の多くの研究と同様に, 平常事態に怙けるリーダーシップが, その平常事態にお けるフォロワーのパフォーマンスに及ぼす効果を検討し つつ, 加えて, 突発的な緊急異常事態が生起した時, そ の異常事態に対してフォロワーがとる対処行動（「異常 事態対処行動」）に及ぼす効果をむ同時に測定し, 検討
するのである。

$$
\text { リーダーシップ }
$$

次に本研究で検討したリーダーシップ行動について述 べる。本研究では, リーダーシップ PM 論 (三隅, 1984) に基づきリーダーシップ行動類型の効果を検討した。

PM 論においては, 集団の機能的要件としての集団目 標達成機能, 集団維持機能に基づいて, 前者を促進する リーダーシップ行動をリーダーシップ P行動, 後者を促 進するリーダーシップ行動をリーダーシップ M行動と称 する。乙れまでの研究で, IBM カードの穿孔数を数える といった単純作業に抢ける作業量（三隅・白樫，1964）, 逆アルファベット文字を模写するといった学習課題にお ける学習過程 (三隅・佐藤, 1968), 緊急恐怖状況下で の迷路脱出行動（釘原・三隅, 1984）などの従属変数に 及ぼすリーダーシップ行動類型の効果が検討されてきた。 その結果, 次のような効果性の順位がほぼ一貫して見い だされたのである。すなわち, P 行動, M行動両者を併 せむった PM 型が最も効果性が高く, 次いで $\mathrm{M}$ 型, $\mathrm{P}$ 型 乙続き（短期的には逆の結果を示すとともある）, P 行 動むM行動む弱い $\mathrm{pm}$ 型は最低の効果性を示した。

ここで, P行動, M行動という概念は, 組織や集団の 相違を越えて, 普遍的に存在する一般行動形態について の概念である。言いかえれば, 組織や集団の種類を異に すれば, その組織や集団に固有の $\mathrm{P}$ 行動の特殊形態や $\mathrm{M}$ 行動の特殊形態が存在すると考えられるのである。実際, てれまでに行われた因子分析的研究であ, 一般企業, 官 公庁, 小中学校, 大学のスポーツサークルなど, その組 織, 集団に固有の因子, すなわち特殊形態が見いだされ ている。

しかるに, 従来の実験的研究に扔いては, P行動, M 行動として実験的に導入された行動形態は微視的には複 合的なあのであったと考察される。すなわち, リーダー シップ $\mathrm{P}$ 行動は, 各々の集団成員の個人目標の達成のよ うに集団内の個人により志向したものと, 集団の目標達 成や集団としての課題解決のように集団により志向した あのとに分化して考察するてとができよう。例えば, 三 隅・白整（1964）など, 従来の研究に扔いては, 前者の 例として「急いで」「もっと早く」などのリーダーシッ プ発言が用いられ, 後者の例として,「このグループが 一番まずい」「他のグループより遅れています」などが 用いられ, 両者が混在していた。厳密には個人志向の場 合す集団に関与する側面が混在すると考えられ, 逆に, 集団志向の場合にも個人志向的な側面が混在すると考え られるので, 両者は完全に独立ではなく, 両者の相違は 強調点の相違である。しかし, 従来の研究では混在して 
矢守・三隅：緊急異常事態発生時の対処行動に及ぼす平常時リーダーシップ行動の効果

いた両者を強調点の相違によって区別することは重要で あると考えられる。同様に，M行動においてあ個人的配 慮などのように個人志向的な場合と集団としての連帯感 や一体感の強調というように集団により志向した場合が 考えら机る。従来の研究では, 前者の例として,「抢ち ついて」「たいへんです刘」といったリーダーシップ発 言が，後者の例として，「仲良く進めましょう」などが 用いられてきた。上述した集団志向的なリーダーシップ 行動に関して, Zander (1982) は各集団成員の個人目 標を強調するだけでなく, 集団目標そのあのを強調する リーダーシップの重要性を指摘しており，また，各集団 成員に与えられた個人的な課題に対する意欲・満足度を 高めるだけでなく，組織体・集団そのものに対するコミ ットメント，一体感を高めるようなリーダーシップの重 要性を指摘したものに Peterson (1982) がある。

そこで, 本研究では, P行動として, 集団成員一人一 人に対して個人目標の達成を強調することによって，集 団の目標達成機能を促進させるのではなく, 集団目標そ のあのの達成を強調するリーダーシップ行動をも導入し た。また，M行動として，集団成員一人一人に対して配 慮を示し, 不必要な緊張を緩和し, 成員が集団から離脱 するてとを防止するてとによって，集団維持機能を促進 させるのではなく, 集団としてのまとまり,すなわち, 集団凝集性そのあのを強調するリーダーシップ行動をむ 導入した。

したがって, 本研究には次の 7 つのリーダーシップ行 動類型を導入したことになる。 $\mathrm{P}_{1}$ 型（個人目標達成強 調型）は, 従来のP型に相当し, 集扵成員一人一人に対 して個人目標の達成を強調し, それに対して圧力をかけ るリーダーシップである。 $\mathrm{M}_{1}$ 型（個人的配慮・緊張緩 和型）は, 従来のM型に相当し, 集団成員一人一人に対 して配慮を示し，作業に伴う緊張感・圧力感を緩和する リーダーシップである。 $\mathrm{PM}_{1}$ 型は, 従来の $\mathrm{PM}$ 型に相 当し, $P_{1}, M_{1}$, 両者を兼的備えたリーダーシップである。 $\mathrm{pm}$ 型は, 従来通り, $\mathrm{P}_{1}, \mathrm{M}_{1}$, 両者亡む弱いリーダー シップである（本来は $\mathrm{pm}_{1}$ 型と記すべきであるが，以 下 $\mathrm{pm}$ 型と略称する)。 $\mathrm{P}_{2}$ 型（集団目標達成強調型） は, 集団成員一人一人の個人目標の達成を強調するので はなく，集団全体として達成すべき目標，つまり，集団 目標の達成を強調し, 圧力をかけるリーダーシップであ る。 $\mathrm{M}_{2}$ 型（集団凝集性強調型）は, 集団成員一人一人 に対して働きかけるてとで集団の維持をはかるのではな く, 集団全体に対して集団としてのまとまり，凝集性を 強調するリーダーシップである。 $\mathrm{PM}_{2}$ 型は, $\mathrm{P}_{2}, \mathrm{M}_{2}$ ， 両者を兼㸚備えたリーダーシップである。

\section{本研究の目的}

以上述べた本研究の目的を概括すれば以下のようにな る。

第 1 亿,「平常事態パフォーマンス」と「異常事態対 処行動」を実験的に明確に分離するととが可能な実験設 定を行ない，同一の被験者を用いて，平常事態における リーダーシップ行動が両者（「平常事態パフォーマンス」 と「異常事態対処行動」）に及ぼす効果を比較検討する。

第 2 亿,リーダーシップに関する従来の実験的研究で は検討されていなかった，集団目標と集団凝集性を強調 するリーダーシップ行動を, 集団目標強調型の $\mathrm{P}_{2}$ 型, 集団凝集性強調型の $\mathrm{M}_{2}$ 型，両者を兼敉備えた $\mathrm{PM}_{2}$ 型 として導入し, 従来の PM 4 行動類型とその効果性を 比較する。

\section{方法}

\section{被 験 者}

大学生女子70名で, $\mathrm{P}_{1}$ 型, $\mathrm{M}_{1}$ 型, $\mathrm{PM}_{1}$ 型, $\mathrm{P}_{2}$ 型, $\mathrm{M}_{2}$ 型, $\mathrm{PM}_{2}$ 型, $\mathrm{pm}$ 型の各リーダーシップ条件に 10 名 ずつランダムに割り当てた。

\section{課 題}

リーダー (男性), 被験者（女性）, 実験協力者（女性） 一いわゆるサクラであり, 被験者の協同作業者を装っ た一一から成る 3 人集団を構成し, 被験者には IBM 力 一ドの穿孔コラムの位置をチェックし，その結果を記録 用紙と呼ばれる用紙に記入するという単純作業（カウン 卜係と呼んだ）を課した。サクラは被験者が記入した記 録用紙のデータをコンピューターに入力する作業（コン ピューター係と呼んだ）を行なった。また，リーダーと サクラは予姆諫を受けており, 一定のシナリオ(「手続 き」の項を参照）に従って行動した。

\section{装置}

実験は，作業室と分析室と呼ばれる 2 室を用いて行な った。その配置を Fig. 1 亿示す。作業室には,リーダ 一席, 被験者席, サクラ席, および, 分析室との連絡用 の電話, さらに, 被験者の行動を記録するためのビデオ カメラ，音声を記録するための集音マイクを設置した。 被験者席には，作業に用いる IBM カード，記録用紙が 置かれていた。リーダー席には，作業の役割分担を決定 するための「選定くじ」（被験者はカウント係に，サク ラはコンピューター係に選ばれるように予め作為が施さ れていた), サクラ席のコンピューターと分析室のメイ ンコンピューターとが接続されているととを被験者に信 用させるためのコンピューターネットワーク装置, 被験 者が記入を終えた記録用紙をサクラ側に転送するための 


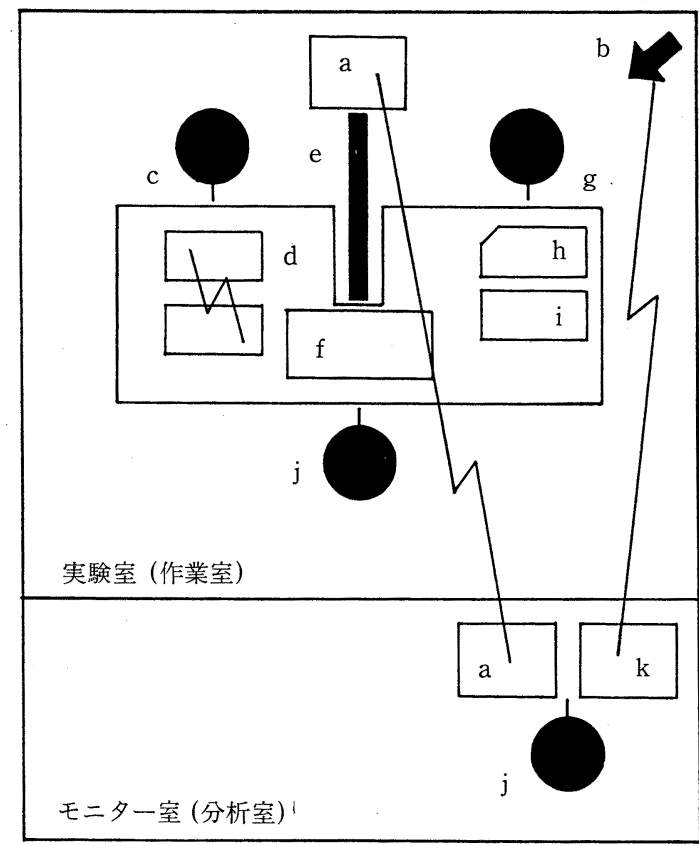

Fig. 1 実験室（作業室）とモニター室（分析室）

（注） $\mathrm{a}$ ：連絡用の電話 $\mathrm{g}$ : 被験者席

$\mathrm{b}:$ :ビデオカメラ h $\mathrm{h}$ IBM カード

c：サクラ席 i : 記録用紙

$\mathrm{d}$ : 作業用コンピューター $\mathrm{j}:$ リリーダー席

$\mathrm{e}$ : 衝立 $\mathrm{k}$ ：ビデオモニター装置

f：記録用紙転送用ボックス

記録用紙受渡し用の箱が置かれていた。サクラ席には, 作業に用いるコンピューターが置かれていた。連絡用の 電話は, 被験者席とサクラ席の後方, 各々の座席から約 1メートルの位置に設置されていた。ビデオカメラと集 音マイクは, 被験者にはその存在を気づかれないように 設置した。

一方, 分析室には, 作業室との連絡用の電話, 作業室 の状況をモニターするためのモニター装置が設置されて
おり, 実験者（リーダー）は，作業室におりる被験者の 行動, 発言を観察するととが可能であった。また, 実験 室の映像と音声はすべてビデオテープに記録された。

\section{手続き}

独立変数: 各リーダーシップ条件に応じたリーダーシ ップ発言を, 一定のシナリオに従って行なった。各リー ダーシップ条件におけるリーダーの主たる発言内容を Table 1 亿示す。各条件とも, リーダーシップ発言は計 7 回なされたが, Table 1 に示した発言内容と機能的に 等価な発言を計 7 回行なった。

従属变数：次の 3 つの従属变数を測定した。第 1 の従 属変数「平常事態パフォーマンス」は, 被験者が作業時 間内に処理を終えた IBM カードの合計枚数であった。 第 2 の従属変数「異常事態対処行動」は, 以下のように 測定した。まず，作業時間内に不自然でない理由でサク ラが作業室を離れる時間を設けた。リーダーは作業上の 指示を行なう時以外は分析室に待機していたので，ての 間は作業室で作業をしているのは被験者だけであった。 そして, ての時間帯に合わせてサクラが使用しているコ ンピューターのアラーム音が鳴る（被験者の対応が何む なければ 3 分間鳴り続けた）という突発的な異常事態を 生起させた。乙の時, 被験者がとりうる行動は次の 4 水 準に分けられた。レベルが上がるほど効果的な対処行動 である。

（a）異常事態発生後，すぐに備えつけの電話で分析 室のリーダーに電話連絡する (レベル 4)。

（b）異常事態発生後, 自己の課題である IBM カー ドの処理を 1 枚以上行なってから分析室のリーダーに電 話連絡する（レベル 3 )。

（c）異常事態発生後 2 分たって子被験者からの電話 連絡がない場合, 分析室のリーダーの側から作業室に電 話をかけたが，その電話には応じる（レベル2）。

（d）アラーム音に対しても，電話連絡に対しても何

Table 1 主たるリーダーシップ発言

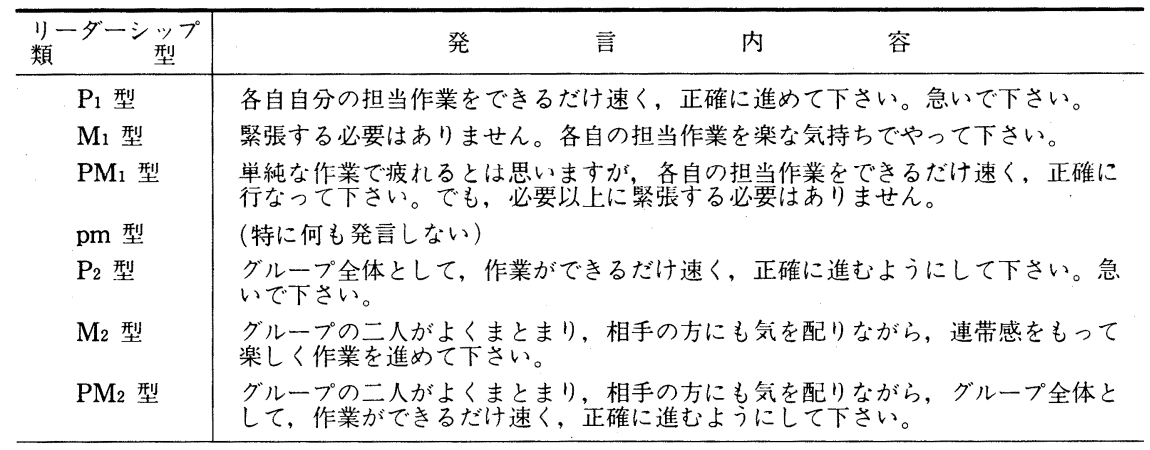


矢守・三隅：緊急異常事態発生時の対処行動に及ぼす平常時リーダーシップ行動の効果

ら対処を行わず，自己の作業を続ける（レベル 1)。

第 3 の従属変数は作業後に実施した「質問紙」である。 てれはリーダーシップ行動に関する被験者の認知, 作業 に対する意欲・満足度などについて問うあのであった。

手続き：実験手続きは以下の通りである。

〔1〕実験は作業能率记関する研究の一環であるという インストラクションのあとで行なった。まず, 作業の概 略を被験者とサクラに説明し, 特に, 以下の点を強調し た。第 1 亿, 役割分担は「くじ」で決定されること。第 2 亿, まずカウント作業, 次いでコンピューター作業と いう流れ作業によって集団全体の作業が進行するてと。 第 3 に, サクラのコンピューターから分析室のメインコ ンピューターにデータが自動的に送られ, そのデータが 集団の最終的な作業成績となり, 分析されること。第 4 に, カウント係の記録ミス, コンピューター係の入力ミ ス, 操作ミスに注意して作業を行うこと。特にコンピ ューターの操作ミスなど, コンピューターに異常が発生 した時にはアラーム音（警告音）が鳴るとと。第 5 亿, リーダーは指示を行なう時以外は分析室に待機している ので, 作業に関して不明な点がある時は電話で分析室の リーダーに連絡するてと。第 6 亿, 作業時間は前半, 後 半各20分の合計40分であるてと。

〔2〕予め作為を施した「選定くじ」によって被験者と サクラの作業分担を決定した後, 約 2 分間の練習作業を 行なった。

〔3〕前半の作業時間開始時に, リーダーシップ発言 (1 回目）を行なった。

〔4〕作業中, サクラは被験者の作業のペースよりも カード数枚分遅れてコンピューターの入力作業を行なう という一定の作業ペースを守った。つまり, 被験者がサ クラの作業ペースに影響されることはなく, 被験者の作 業ペースが集団全体の作業ペースを決定した。

〔5〕作業開始 5 分後, リーダーは作業室を退室し, 分 析室に入った。乙の時, リーダーシップ発言（2回目） を行なった。

〔6〕作業開始 10 分後, リーダーは作業室に入室し, リーダーシップ発言（3回目）を行い, その後作業室を 退室した。

７７作業開始20分後, リーダーが作業室に入室し, 休 顖時間に入った。乙の時, リーダーシップ発言 (4 回目) を行なった。約 1 分間の休稳の後, リーダーが後半の作 業時間の開始を告げた。乙の時, リーダーシップ発言 (5 回目）を行い, その後, リーダーは作業室を退室した。

〔8〕作業開始25分後, 作業室で被験者だけが作業をし ている状況を作るために, サクラを作業室から退室させ
た。すなわち, サクラに外部から電話がかかっていると 告げ, 電話が終了次第, 作業に戻るように指示した後, 作業室から退室させた。被験者付対しては，そのまま作 業を続けるように依頼した。乙の時, リーダーシップ発 言（6回目）を行い, この後すぐ,リーダーも作業室を 退室した。

（9）作業開始28分後, 異常事態が発生した。

（a）予め入力しておいたコンピュータープログラム に従って, コンピューターの異常を示すアラーム音が鳴 り始め, 乙れは被験者の対応がなければ， 3 分間鳴り続 けた。

（b）アラーム音に対して被験者の対応がない時, つ まり, 被験者からの電話連絡がない時, アラーム音発信 の 2 分後, 分析室のリーダーの側から作業室に電話をか けた (=電話連絡 (1 回目))。

(c) 1 回目の電話連絡に対しても被験者の対応が ない時, その後, すぐに再度電話をかけた（=電話連絡 (2 回目))。

〔10〕上記の異常事態に対する被験者の対応によって, 次のいずれかのシナリオに従って,リーダーは行動した。

（A）上記 [10〕の（a）で被験者が対応した時，すな わち, 被験者がアラーム音を電話で報告した時は, リー ダーがその電話に応じ, 作業室に入室し, アラーム音を 止め, 作業を続行させた。

（B）上記 [10]の（b)（c）で被験者が反応した 時, すなわち, 作業室にかかった電話に応答した時は, リーダーが分析室でメインコンピューターが不調である と告げ，作業室に異常がないかを被験者に尋ねた。それ に対する被験者の回答（アラーム音のととを述べる）を 確認した後, リーダーは作業室に入室し, アラーム音を 止め, 作業を続行させた。

（C）被験者の対応がまったくなかった時は，リー ダーは何む行わないで, 分析室でアラーム音の休止を待 った。

〔11〕乙の後 (作業終了約 7 分前), サクラは作業室に 戻り, 作業を続行した。

〔12〕作業終了 5 分前, リーダーは作業室に入室し, リーダーシップ発言（7回目）を行なった。

(13) 作業開始40分後, 作業を終了し, 被験者, さくら 両者に対して作業後の質問紙の回答を求めた。回答が終 了次第, ディブリーフィングを行い, 謝礼を渡して実験 を終了した。 
結

果

\section{1 平常事態パフォーマンス}

結果は, Fig. 2 の通りである。分散分析 $(F(6,53)=$ 7.46: $p<.001)$ と最小 2 乗法による下位検定の結果, 「平常事態パフォーマンス」に対して7つのリーダーシッ プ類型は, $\mathrm{P}_{2}$ 型, $\mathrm{P}_{1}$ 型, $\mathrm{PM}_{2}$ 型, $\mathrm{PM}_{1}$ 型の高パフォ ーマンス群之 $\mathrm{pm}$ 型, $\mathrm{M}_{1}$ 型, $\mathrm{M}_{2}$ 型の低パフォーマン ス群に分離されるてとが明らかとなった。乙れは, 従来 のPM 4 類型に関しては先行研究の結果と対応するす のである。かつ, 新しく導入した $\mathrm{P}_{2}$ 型, $\mathrm{M}_{2}$ 型, $\mathrm{PM}_{2}$ 型は, それぞれ, $\mathrm{P}_{1}$ 型, $\mathrm{M}_{1}$ 型, $\mathrm{PM}_{1}$ 型と対応するパ フォーマンスを示している。よって, てれらのリーダー シップ類型は,「平常事態パフォーマンス」に対しては, 従来の各類型と同様の効果性を示すととが明らかとなっ た。

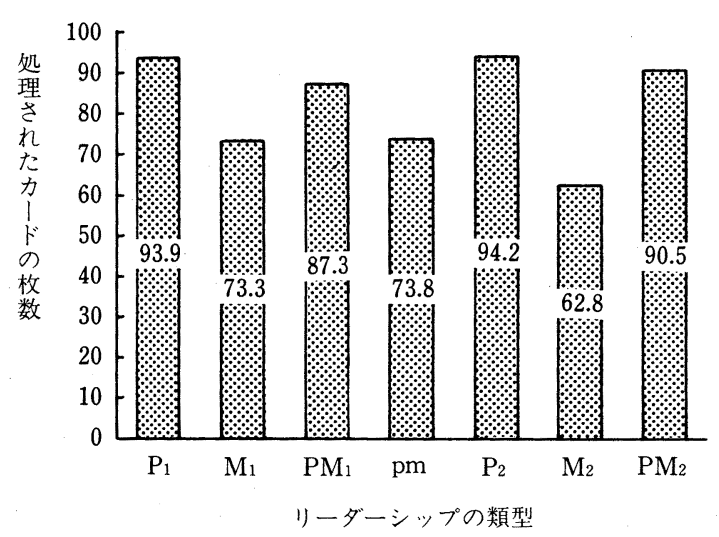

Fig. 2 リーダーシップ類型別「平常事態 パフォーマンス」

\section{2 異常事態対処行動}

結果は, Fig. 3 の通りである。まず, 7 つのリーダー シップ類型と対処行動との関連を分析したところ, 対処 行動の各レベルの生起比率が各類型で同一であるとした モデルよりあ，異なると考えたモデルの方が妥当である ことが見いだされた（生起比率は同一としたモデルの AIC (赤池情報量基準) $=194.88$, 異なるとしたモデルの $\mathrm{AIC}=191.34)$ 。すなわち, リーダーシップ類型によって, 異常事態対処行動の効果性は異なると考えられる。

そこで, 次にどのリーダーシップ類型間に差異が見ら れるかを検討するために，7つのリーダーシップ類型か ら各々 $2 つ を$ 組み合せ, AIC を用いた同様の分析法に よって, 各々の差異を検討した。その結果, $\mathrm{PM}_{2}$ 型, $\mathrm{PM}_{1}$ 型, $\mathrm{M}_{2}$ 型, $\mathrm{M}_{1}$ 型, $\mathrm{P}_{2}$ 型, $\mathrm{pm}$ 型, $\mathrm{P}_{1}$ 型の順に 効果性が高いてと, 全体として従来の 4 類型（1 型）よ りも新しく導入した 3 類型 (2 型) の効果性が高いこと, 従来の類型 ( 1 型) と新類型 ( 2 型) を総合すれば PM 型, $\mathrm{M}$ 型, $\mathrm{P}$ 型の順に効果性が高いとと, $\mathrm{P}_{1}$ 型の効果 性が非常に低く, $\mathrm{PM}_{2}$ 型の効果性が最も高いことが見 いだされた。

より詳細に検討すると, $\mathrm{P}_{1}$ 型と $\mathrm{P}_{2}$ 型の比較につい ては，4レベルに分割した対処行動での比較において効 果性が異なることが見いだされた（同一としたモデルの $\mathrm{AIC}=55.41$ ，異なるとしたモデルの $\mathrm{AIC}=54.68) 。 し か$ し, レベル 1 とそれ以外という2 群に分けて比較すると より顕著な差異が認められた（同一としたモデルの AIC $=28.93$, 異なるとしたモデルの AIC=27.47)。すなわち, $\mathrm{P}_{2}$ 型は $\mathrm{P}_{1}$ 型と比べて「まったく対処行動をしない」と いうレベル19生起頻度を低減しているという点で, よ り効果的なリーダーシップであると言えよう。 $\mathrm{M}_{1}$ 型と $\mathrm{M}_{2}$ 型の比較については, 明確な差異は認められなかっ

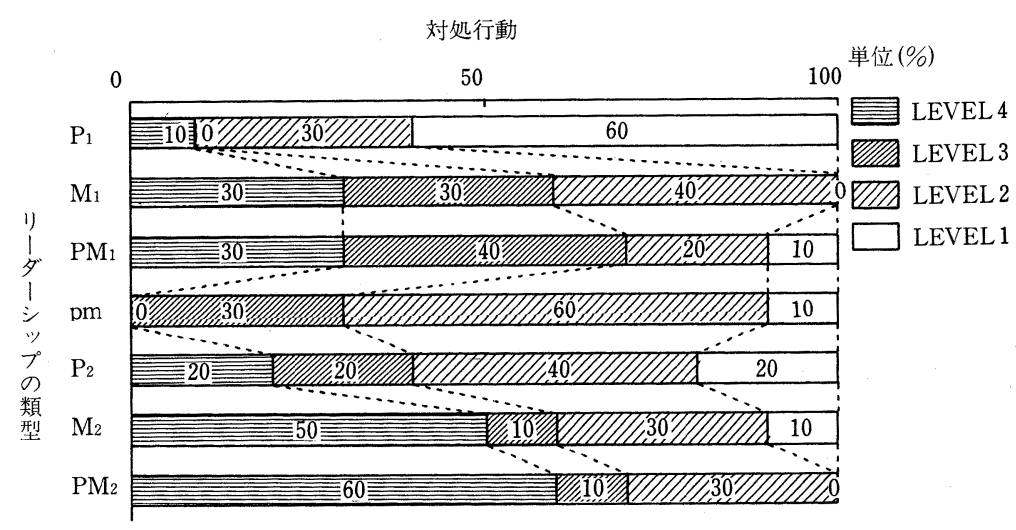

Fig. 3 リーダーシップ類型別「異常事態対処行動」 
矢守・三隅：緊急異常事態発生時の対処行動に及ぼす平常時リーダーシップ行動の効果

た。 $\mathrm{PM}_{1}$ 型と $\mathrm{PM}_{2}$ 型の比較については， 4 レベルに 分割した際は，明確な差異は見いだされなかった。しか し，乙の両者は，レベル 4 とレベル 3 の合計生起頻度は 同じである（両者とも7）にもかかわらず，最も効果的 な対処行動であるレベル 4 の生起比率は $\mathrm{PM}_{2}$ 型が60\% であるのに対して, $\mathrm{PM}_{1}$ 型は $30 \%$ ある。そてで, レ ベル 4 とレベル 3 の生起頻度だけを検討したとてろ, 差 異が存在するととが確認された（同一であるとしたモデ ルの $\mathrm{AIC}=28.93$ ，異なるとしたモデルの $\mathrm{AIC}=27.47$ )。 すなわち, $\mathrm{PM}_{1}$ 型と $\mathrm{PM}_{2}$ 型との間には明確な差異は認 められないが, $\mathrm{PM}_{2}$ 型が, 最も効果的な対処行動であ るレベル 4 の生起率を増大させるという点で, より効果 的なリーダーシップと考えられるのである。

\section{3 平常事態パフォーマンスと異常事態対処行動の総 合指標}

「問題」の項で述べた通り, 本研究の特徴の一つは, 同一の被験者を用いて,「平常事態パフォーマンス」と 「異常事態対処行動」の両者に及ぼすリーダーシップの 効果を比較検討する点にある。そこで本節では, 両者を まとめた総合指標を作成し, リーダーシップ条件間の差 を検討した。結果をTable 2 亿示す。

分析にあたっては,「平常事態パフォーマンス」を全 体平均値 (82.3) で 2 分割し (優群と劣群), 「異常事態 対処行動」をレベル 4,3 (優群) とレベル 2, 1 (劣 群)の 2 群に分け, 「平常事態パフォーマンス」, 「異常事 態対処行動」両者と屯優れる,「平常事態パフォーマン ス」のみ優れる, 「異常事態対処行動」のみ優れる, 両 者とあ劣る, の合計 4 カテゴリーを設定した。リーダー シップ条件でとに各カテゴリーの人数分布を分析した結 果, 総合指標に対してリーダーシッブ類型の効果性は異 なることが見いだされた (同一であるとしたモデル AIC =199.46，異なるとしたモデルの AIC=185.66)。すなお ち, $\mathrm{PM}_{2}$ 型, $\mathrm{PM}_{1}$ 型は両者に対して効果的であり, $\mathrm{P}_{2}$
型， $\mathrm{P}_{1}$ 型は「平常事態パフォーマンス」に対してのみ 効果的, $M_{2}$ 型, $M_{1}$ 型は「異常事態対処行動」に対し てのみ効果的, $\mathrm{pm}$ 型は両者に対して効果性が低い, と いう全体的傾向か認められる。また, PM 型, P型につ いて従来の類型（1 型）と新類型（2 型）を比較すれば, 2 型の方が「異常事態対処行動」に対してより効果的で あることは 2 節で述べた通りである。

\section{4 異常事態対処行動と関連する要因}

どのような要因が「異常事態対処行動」の効果性之関 連していたかを検討するため, 質問紙に含まれていた項 目を説明変量（合計25要因を導入した）とし, 対処行動 を目的变量として, 対処行動と最も密接な関係にあった 变量を探る探索的な分析を行なった（坂元・石黒・北川， 1983)。結果をTable 3,4 亿示す。

AIC の值が低い説明要因ほど目的変量との関連性が

Table 3 「集団へのコミットメント」と 「異常事態対処行動」

\begin{tabular}{c|c|c|c|c}
\hline & \multicolumn{3}{|c|}{ 目的変数一対処行動のレベル(実数) } \\
\cline { 2 - 5 } & レベル-1 & レベル-2 & レベル-3 & レベル-4 \\
\hline コミットメント大群 & $0 \%$ & $13 \%$ & $33 \%$ & $54 \%$ \\
$(2-3$ 点 $)$ & $(0 / 15)$ & $(2 / 15)$ & $(5 / 15)$ & $(8 / 15)$ \\
\hline $\begin{array}{c}\text { コミットメント小群 } \\
(4-10 \text { 点 })\end{array}$ & $\begin{array}{c}22 \% \\
(12 / 55)\end{array}$ & $\begin{array}{c}40 \% \\
(22 / 55)\end{array}$ & $\begin{array}{c}16 \% \\
(9 / 55)\end{array}$ & $\begin{array}{c}22 \% \\
(12 / 55)\end{array}$ \\
\hline
\end{tabular}

Table $4 「$ 無理な圧力感」と「異常事態対処行動」

\begin{tabular}{c|c|c|c|c}
\hline & \multicolumn{3}{|c}{ 目的変数一対処行動のレベル(実数) } \\
\cline { 2 - 5 } & レベル-1 & レベル-2 & レベル-3 & レベル-4 \\
\hline $\begin{array}{c}\text { 無理な圧力感大群 } \\
(1-4 \text { 点 })\end{array}$ & $35 \%$ & $13 \%$ & $22 \%$ & $30 \%$ \\
$(8 / 23)$ & $(3 / 23)$ & $(5 / 23)$ & $(7 / 23)$ \\
\hline $\begin{array}{c}\text { 無理な圧力感小群 } \\
(5 \text { 点 })\end{array}$ & $8 \%$ & $45 \%$ & $19 \%$ & $28 \%$ \\
$(4 / 47)$ & $(21 / 47)$ & $(9 / 47)$ & $(13 / 47)$ \\
\hline
\end{tabular}

Table 2 リーダーシップ類型別「平常事態パフォーマンス」・

「異常事態対処行動」の総合指標

\begin{tabular}{|c|c|c|c|c|c|c|c|}
\hline & $\mathrm{P}_{1}$ 型 & $\mathrm{M}_{1}$ 型 & $\mathrm{PM}_{1}$ 型 & pm 型 & $\mathrm{P}_{2}$ 型 & $\mathrm{M}_{2}$ 型 & $\mathrm{PM}_{2}$ 型 \\
\hline $\begin{array}{l}\text { 「平常事態バフォマンス」一劣 } \\
\text { 「異常事態対処 行動」一劣 }\end{array}$ & 2 & 3 & 1 & 5 & 0 & 4 & 1 \\
\hline $\begin{array}{l}\text { 「平常事態パフォーマンス」一劣 } \\
\text { 「異 常 事態 対 処 行動」一優 }\end{array}$ & 0 & 4 & 2 & 2 & 1 & 6 & 1 \\
\hline $\begin{array}{l}\text { 「平常事態パフォーマンス」一優 } \\
\text { 「異常 事態対処行動」一劣 }\end{array}$ & 7 & 1 & 2 & 2 & 6 & 0 & 2 \\
\hline $\begin{array}{l}\text { 「平常事態パフォーマンス」一優 } \\
\text { 「異 常 事態対 処 行動」一優 }\end{array}$ & 1 & 2 & 5 & 1 & 3 & 0 & 6 \\
\hline
\end{tabular}


強く, AIC の值が負である説明要因は目的変量と統計 的に有意に関連があると認められる。乙の結果, 検討し た25要因中「異常事態対処行動」と最も強く関連してい

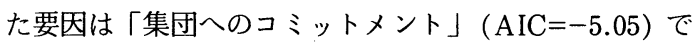
あった。乙の要因は, 質問項目「あなたは,グループ全 体の作業（カウント係+コンピューター係）の進みぐあ いについて気になりましたか」と質問項目「あなたは， グループ全体の作業（カウント係+コンピューター係） の進行に責任を感じましたか」の得点を加算したもので あり, これは集団目標の達成に対する動機づけ（以下， 「集団へのコミットメント」と呼ぶ）を測定するととを 意図して導入された項目であった。「集団へのコミット メント」が大であるほど「異常事態対処行動」が効果的 となっている。

また, 密接な関連とは言えない $(\mathrm{AIC}=-2.09)$ が,「異 常事態対処行動」の効果性が最む低いレベル 1 と「平常 時の作業に対する無理な圧力感」(質問項目「あなたは, 作業中（カウント）, リーダーから無理な圧力を感じる ことがありましたか」）との間に関連性が見られた。レ ベル 1 は, 圧力感小群と比較して, 圧力感大群に多いの である。

5 「集団へのコミットメント」,「無理な圧力感」と リーダーシップ

2節でリーダーシップと対処行動との関連性を検討し, 4 節で「集団へのコミットメント」,「無理な圧力感」が 対処行動と関連していることが明らかとなったので，本 節では, リーダーシップと上記の 2 要因との関連性を検 討した。結果を Fig. 4,5 亿示す。

分散分析 $(F(6,63)=2.91 ; p<.02)$ と最小 2 乗法に よる下位検定の結果，「集団へのコミットメント」は,

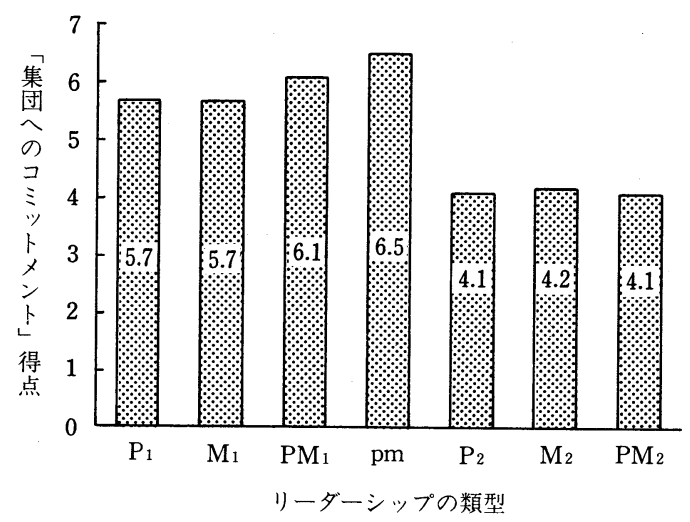

Fig. 4 リーダーシップ類型別「集団への コミットメント」

（注）得点が小ほど「集団へのコミットメント」が大

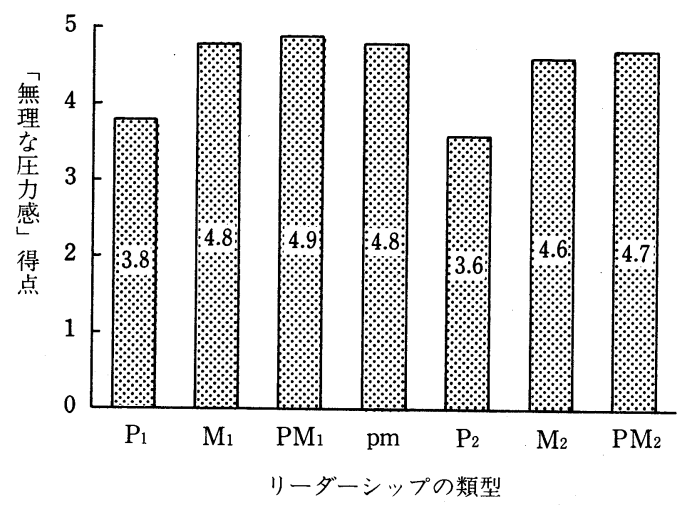

Fig. 5 リーダーシップ類型別「無理な圧力感」

（注）得点が小ほど「無理な圧力感」が大

$\mathrm{PM}_{2}$ 型, $\mathrm{P}_{2}$ 型, $\mathrm{M}_{2}$ 型リーダーシップ下に㧠いて, $\mathrm{PM}_{1}$ 型, $\mathrm{P}_{1}$ 型, $\mathrm{M}_{1}$ 型, pm 型リーダーシップ下より有意に 高いととが見いだされた。

「無理な圧力感」に関しては, 分散分析 $(F(6,63)=$ $4.13 ; p<.002)$ と最小 2 乗法による下位検定の結果, $\mathrm{P}_{2}$ 型, $\mathrm{P}_{1}$ 型リーダーシップで他のリーダーシップ類型 より有意に高いことが見いだされた。

\section{考察}

本研究では, 平常事態に抢けるリーダーのリーダーシ ップ行動が，平常事態における部下の作業量（「平常事 態パフォーマンス」）之緊急異常事態発生時における部 下の対処行動（「異常事態対処行動」）に及ぼす効果を実 験的に検討した。リーダーシップ行動類型はリーダーシ ップ PM 論に基づいて導入した。その際, 従来の研究で は充分に検討されていなかった，集団目標と集団凝集性 を強調するリーダーシップ行動を新しいリーダーシップ 行動類型（集団目標達成強調型の $\mathrm{P}_{2}$ 型, 集団凝集性強 調型の $\mathrm{M}_{2}$ 型，両者を兼社備えた $\mathrm{PM}_{2}$ 型）として導入 し, 個人志向型の 4 類型（個人目標達成強調型の $\mathrm{P}_{1}$ 型, 個人的配慮・緊張緩和型の $\mathrm{M}_{1}$ 型，両者を兼㛊備えた $\mathrm{PM}_{1}$ 型, 両者ともに弱い $\mathrm{pm}$ 型）と区別して, 両者の 効果性を比較検討した。

実験の結果, リーダーシップ行動類型の効果性に関し て次のような結果が得られた。すなわち, $\mathrm{PM}_{2}$ 型が「平 常事態パフォーマンス」,「異常事態対処行動」両者に対 して最も効果的であり， $\mathrm{PM}_{1}$ 型がそれに次いだ。また， $\mathrm{P}_{1}$ 型は「平常事態パフォーマンス」に対してのみ効果 的あり, $\mathrm{M}_{2}$ 型は「異常事態対処行動」に対してのみ効 果的であること, pm 型は両者に対して効果性が低いて 
矢守・三隅：緊急異常事態発生時の対処行動に及ぼす平常時リーダーシップ行動の効果

となどが見いだされた。

さらに,「異常事態対処行動」と最む強く関連する要 因として，集団目標達成に対する動機づけの程度（「集 団へのコミットメント」）が見いだされ，「集団へのコミ ットメント」が高いフォロワーほど効果的な対処行動を とることが明らかとなった。また，平常時の作業に対す る「無理な圧力感」が効果的な対処行動の生起を抑制す ることも見いだされた。

以下, 乙れらの結果について若干の考察を試みてみよ う。

第 1 K, $\mathrm{PM}_{2}$ 型が最も効果的な対処行動を生起させ た点に関して考察しよう。Fig.4によれば, $\mathrm{PM}_{2}$ 型リー ダーシップは，他の類型と比較して相対的に「集団への コミットメント」が高く, また, 「集団へのコミットメ ント」が高いほど「異常事態対処行動」が効果的になる 傾向が見いだされている (Table 3)。したがって, $\mathrm{PM}_{2}$ 型が最む効果的な対処行動を生起させたのは，「集団へ のコミットメント」を高めたからであると考察されよう。 また, $\mathrm{PM}_{2}$ 型リーダーシップ下で「集団へのコミット メント」が最む高かったてとは以下のように考察されよ う。すなわち, $\mathrm{PM}_{2}$ 型リーダーシップは集団目標の達 成と集団疑集性の重要性の両者を強調したために, フォ ロワーは自分に与えられた作業を能率的に進行させるだ けでなく，他成員と協力して集団全体の作業を効果的に 遂行しようとする動機づけ(「集団へのコミットメント」) を有するようになったのであろう。

一方, Table 3 亿示されているように「集団へのコ ットメント」が高いフォロワーほど効果的な「異常事態 対処行動」をとっている。乙のととは以下のように考察 される。すなわち, 本研究の実験課題においては, 被験 者の作業課題 (IBM カードの穿孔位置のチェック) と共 同作業者の作業課題（チェック結果のコンピューター入 力）とは, 前者の作業結果を用いて後者が作業を行なう という点で関連性のあるあのであった。しかも, 両者の 結果が総合されて集団全体としての作業成績が計算され るととは全リーダーシップ条件で明確に被験者に知らさ れていた。すなわち, 本研究における実験課題はいわゆ る conjunctive task (Steiner, 1972) であったのである。 ただし, まず被験者, その次に共同作業者という順序の 流れ作業であったので, 被験者は共同作業者の課題の遂 行とはまったく独立に自己の作業を遂行することが可能 であった。つまり, 共同作業者のコンピューター入力作 業の進行状況とは無関係に自己の作業を継続することす できたのである。このような状況において, 共同作業者 が作業に使用しているコンピューターの異常に対して対
処行動をとるためには, フォロワーがリーダーから直接 与えられた自己の作業を遂行するてと, すなわち, 個人 目標の達成だけでなく, 集団目標の達成に対して動機づ けられているてと，すなわち，「集団へのコミットメン ト」を有しているてとが必要であると考えられるのであ る。

さて, $\mathrm{PM}_{2}$ 型が「集団へのコミットメント」を高め たてとに関連して, Zander (1982) は, 本研究に打ける 「集団へのコミットメント」とほぼ同義の概念である集 団志向的動機づけを個人志向的動機づけと対置して理論 化している。そして, 集団志向的動機づけを高める手段 として, 当該集団のリーダーの役割を重視し,「明確な集 団目標を設定する」，「集団のまとまりや membership を強調する」などの 14 点を挙げている。本研究の $\mathrm{PM}_{2}$ 型のリーダーシップ行動はてれと対応するあのと考えら れる。

また, 吉田（1963）は, 本研究の集団凝集性に相当す る「成員結合」に関して, 集団の目標達成と正機能する 成員結合（協同結合）と，成員結合そのあのと正機能す る成員結合 (人格結合) を区別する必要があると述べて いる。従来，集団凝集性は「集団成員を当該集団にとど まらせようと働きかける力の総体」と概念的に定義され るのが一般的であった (Festinger, 1950)。また, 操作 的には集団成員が他の成員，あるいは，集団全体に対し て抱く魅力を測定した例，集団成員か課題に対して抱く 魅力を測定した例などが混在している。てのうち, 前者 の意味での, すなわち, 他成員に対する魅力に基づくと いう意味での集団凝集性は, 吉田の分類で言えば，「好 きであるから」「魅力があるから」というように成員結 合そのあのと正機能する人格結合に相当するあのである と思われる。一方, 本研究に扔ける $\mathrm{PM}_{2}$ 型リーダーシ ップは, 集団目標と集団凝集性の両者を強調することに よって, 集団目標の達成と正機能する集団凝集性, すな わち, 協同結合を高めたものと考えられる。すなわち, 従来の実験的研究で吟味されていた集団凝集性が, 人格 結合や協同結合が混在し, 両者の区別が不明確なもので あったと考えられるのに対して, 本研究における $\mathrm{PM}_{2}$ 型リーダーシップが高めた集団凝集性は明らかに協同結 合に近いものであったと考察されるのである。

以上, $\mathrm{PM}_{2}$ 型が最む効果的な対処行動を生起させた 点について考察を試みた。ただし, 集団志向的な $\mathrm{P}$ 行動 とM行動を併せもった $\mathrm{PM}_{2}$ 型リーダーシップの効果性 をより一般的に論じるためには, 課題の性質, および, 文化差・国民性の相違も含めたリーダー・フォロワーの おかれた状況などの要因を考慮する必要があろう。 
第 2 に, $\mathrm{P}_{1}$ 型が「平常事態パフォーマンス」に対し ては効果的であったにあかかわらず，「異常事態対処行 動」に対する効果性が非常に低かった点について考察し よう。Fig. 5 によれば, $\mathrm{P}_{1}$ 型リーダーシップ下で「無 理な圧力感」が $\mathrm{P}_{2}$ 型と並んで高く, てれは従来の諸研 究の結果と一致するあのである。そして, てうした「無 理な圧力感」はフォロワーの作業量に対して短期的には 効果的に作用し, 長期的にはマイナスに作用するてとが これまでの研究で見いだされてきた。本研究における 「平常事態パフォーマンス」あ単純作業におけるフォロ ワーの短期的な作業量を測定したものであり, 従来の研 究と同様に,「無理な圧力感」がむしろ効果的に作用し, $\mathrm{P}_{1}$ 型下で「平常事態パフォーマンス」が高くなったの であろう。

一方, $\mathrm{P}_{1}$ 型が勃果的な「異常事態対処行動」の生起 を抑制したてとは, 問題解決場面に打いて特定解決法に 対する「構え (Einstellung)」が $\mathrm{P}_{1}$ 型リーダーシップ 下で強いことを示した藤田（1975）や緊急異常事態の迷 路脱出行動に打ける固着傾向が $\mathrm{P}_{1}$ 型リーダーシップ下 で顕著であるととを示した釘原・三隅（1984）の結果と ほぼ対応するものと思われる。ただし，本研究見いださ れた結果は, フォロワー一人一人に与えられた各自の課 題に扔いて特定の課題解決法に固着することを示した上 記の研究とは異なると考えられる。すなわち, 本研究に おける固着傾向は, 複数の成員から成る集団において, 集団成員が集団内に他に解決すべき問題が生じているに あかかわらず，リーダーから直接与えられた自分の作業 の遂行に固着し, 柔軟な対処行動をとれなかったという 現象であった。従って, この現象は, 緊急異常事態下の 個人的な認知過程, 問題解決過程における固着現象 (池 田，1986）であるだけでなく, 複数の成員から構成され る集団に抢ける対人的な要因㳘響された固着現象であ るという点で, 集団に特有な現象と考えられるのである。

以上,「平常事態パフォーマンス」「異常事態対処行 動」の両従属変数に及ぼすリーダーシップの効果性を,

「集団へのコミットメント」「無理な圧力感」の 2 要因

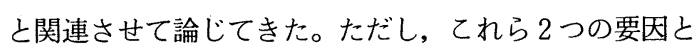
あ, 行動变数測定後に実施された質問紙に基づく認知的 変数である点を考慮する必要があろう。すなわち, 乙れ ら 2 つの要因と従属変数との間の因果関係は必ずしも明 確ではないのである。

最後に, リーダーシップによる事故・災害の防止とい う観点から, 本研究の結果を考察しよう。自然災害時に おける避難行動, 原子力発電所におりる事故など, 異常 の手がかりとなる情報が存在するにもかかわらず，その
時点において適切な対処行動がとられなかったために， 大きな被害を招くという事例が数多く報告されている （矢守・三隅・渥美，1986など）。乙のような事例に関し て, 確かに地震や地滑りに伴う自然災害と発電所や工場 に抢ける事故とは，その形態や性質が異なるであろう。 しかしながら，それらの事故・災害の原因が「人間」と 関わる側面に注目すれば共通の要因も見いだされよう。 すなわち，「たぶん大丈夫だ」「まさか事故など起てらな いだろう」といった思い込みである。こうした思い込み は「正常化の偏向 (Normalcy-Bias)」(Turner, 1976) 之呼ばれているが，災害や事故を予防するあらゆる試み は, 乙の「正常化の偏向」をいかに変容するかに関わる とあ言えよう。乙うした意味において, 本研究は平常時 のリーダーシップによって, 緊急異常事態に抢いて部下 の適切な対处行動を生起させ, 事故・災害を未然に防止 する試みであるとあ言えるのである。

実験の結果, まず, 本研究で検討したような作業集団 に扔いて事故・災害を防止するためには, 集団成員各々 の個人目標の達成のみを強調し, かえって各成員の個々 人の作業遂行に対する固着傾向を生じさせることは有効 ではないととが示唆された。むしろ，「集団へのコミッ トメント」を高め, 集団成員が他成員の作業を含めた集 団全体の目標の達成に対しても動機づけを有するような リーダーシップが事故・災害防止には有効であることが 示唆されたのである。

次に, 緊急異常事態に扔ける何らかの行動（本研究に おいては「異常事態対処行動」) に対して, 緊急異常事 態ではなく, それ以前の平常事態に内包される要因（本 研究に扔いては平常事態に打けるリーダーシップ行動) が影響を及ぼしうる点が示唆された。緊急異常事態にお ける認知的・情動的・対人的要因がその時点での行動に 影響を及ぼすのは当然であろう。例えば, 緊急異常事態 に扔けるリーダーのリーダーシップが対人的影響過程と して避難者の行動に大きな影響を与えることは, すでに 多くの研究で明らかにされている（釘原・三隅, 1984な ど)。乙れに対して, 本研究は平常事態におけるフォロ ワーの作業に対するリーダーシップが, その作業に掞け る生産性だけでなく, 緊急異常事態に扔ける集団成員の 対処行動に対しても影響を及ぼすてとを見いだしたので ある。乙うした意味で, 平常事態に打ける作業の作業量 を高めるだけでなく, 緊急異常事態発生時においてあフ オロワーの効果的な対処行動を生起させ, 事故・災害の 未然防止にあ有効であると考えられる $\mathrm{PM}_{2}$ 型が最も効 果的なリーダーシップであるてとが示唆されよう。 
矢守・三隅：緊急異常事態発生時の対処行動に及ぼす平常時リーダーシップ行動の効果

\section{要約}

本研究は，平常事態におけるリーダーのリーダーシッ プ行動が, 平常事態に扔ける部下の作業の作業量（「平 常事態パフォーマンス」) に及ぼす効果と, 緊急異常事 態発生時に抢ける部下の異常に対する対処行動（「異常 事態対処行動」）に及ぼす効果を実験的に検討したもの である。

「平常事態パフォーマンス」とは, リーダーがフォロ ワーに遂行を命じた作業の作業量であり, 従来の研究で は主としてての「平常事態パフォーマンス」に及ぼす リーダーシップの効果が検討されてきた。一方, 「異常 事態対処行動」とは, 各集団成員がリーダーから直接与 えられた作業とは直接的な関連をむたないが, 集団全体 の効果性に対してはネガティブな影響を及ぼしかねない ような突発的な異常事態伩対するフォロワーの対処行動 のことである。

リーダーシップは三隅（1984）の PM 論に基づいて検 討した。ただし, 従来の研究では微細に検討されていな かった行動形態として, 個々の集団成員に対してのみで はなく, 集団全体に対する影響過程によって, 集団目標 達成と集団の維持という集団の機能的要件を促進する新 しいリーダーシップ行動類型— $\mathrm{P}_{2}$ 型（集団目標達成強 調型), $\mathrm{M}_{2}$ 型 (集団凝集性強調型), $\mathrm{PM}_{2}$ 型 (両者を兼 水備えた型）——導入し, 個人志向型の $\mathrm{P}_{1}$ 型（個人 目標達成強調型), $\mathrm{M}_{1}$ 型 (個人的配慮・緊張緩和型), $\mathrm{PM}_{1}$ 型（両者を兼ね備えた型）, pm 型（両者とも弱い 型）とともにその効果性を比較検討した。

被験者, サクラ, リーダーから成る 3 人集団を実験的 に構成し,「平常事態パフォーマンス」の測度として, 被験者に与えた単純作業に扔ける作業量を設定し,「異 常事態対処行動」の測度として, 被験者の共同作業者を 装ったサクラが作業に用いるコンピューターが異常を示 すアラーム音を発するという緊急異常事態に打いて, 被 験者がとる対処行動を設定した。

実験の結果, $\mathrm{PM}_{2}$ 型が「平常事態パフォーマンス」, 「異常事態対処行動」両者に対して最も効果的であり, $\mathrm{PM}_{1}$ 型がそれに次いだ。また, $\mathrm{P}_{1}$ 型は「平常事態パフ ォーマンス」に対してのみ, $\mathrm{M}_{2}$ 型は「異常事態対処行 動」に対してのみ効果的であるてと, pm 型は両方に対 して効果性が相対的に最す低いことが見いだされた。さ らに, 「異常事態対処行動」の効果性と強く関連する要 因として, 集団目標達成に対する動機づけの程度（「集 団へのコミットメント」), 「平常時の作業に対する無理 な圧力感」が見いだされ，「集団へのコミットメント」
が高いほど対処行動が勃果的となること，「無理な圧力 感」が高いほど対処行動の効果性が劣る傾向が認められ た。乙れらの結果は以下のように考察された。

まず, $\mathrm{PM}_{2}$ 型が, 両従属变数に対する効果性が最も 高かったのは, 集団目標と集団凝集性を強調することに よってフォロワーの「集団へのコミットメント」を高め たてとによると考察された。また, $\mathrm{P}_{1}$ 型が,「平常事態 パフォーマンス」に対してのみ効果的であったてとは, $\mathrm{P}_{1}$ 型で高かった「無理な圧力感」が平常時の作業にお ける短期的な作業量の増大には有効に作用したものの, 柔軟性・適応性が要求される「異常事態対処行動」には ネガティヴに作用したためと考察された。

また，平常時のリーダーシップは同じ平常事態におけ るフォロワーの作業の作業量に対してだけでなく, 緊急 異常事態に打けるフォロワーの対処行動にも影響を及ぼ すととが明らかとなり，乙のととは事故・災害を未然に 防止するという点からも意義をあつものと考察された。

\section{引用文 献}

Festinger, L. 1950 Informal social communication. Psychological Review, 57, 271-282.

Fiedler, F. E. \& Chemers, M. M. 1977 Improving leadership effectiveness: The leader match concept. New York: John Wiley \& Sons.

French, J.R.P. 1941 The disruption and cohesion of groups. Journal of Abnormal and Social Psychology, 36, 361-377.

藤田 正 1975 問題解決過程の構えに及ぼす PM 式 監督類型の影響について 実験社会心理学研究, $15,116-128$.

池田謙一 1986 緊急時の情報処理（認知科学選書 9) 東京大学出版会

釘原直樹・三隅二不二 1984 緊急恐怖状況下の迷路脱 出に及ばすリーダーシップ条件効果に関する実験 的研究 心理学研究, 55, 214-220.

Latane, B. \& Darley, J.M. 1968 Group inhibition of bystander intervention. Journal of Personality and Social Psychology, 10, 215-221.

三隅二不二 1984 リーダーシップ行動の科学(改訂版) 有斐閣

三隅二不二・佐藤静一 1968 作業課題遂行とレミニッ センスに及ぼす PM 式監督行動類型効果— $\mathrm{PM}$ 式指導類型の動機諭的考察 教育・社会心理学研 究, 8, 13-23.

三隅二不二・白樫三四郎 1964 組織体におけるリーダ ーシップ構造一機能に関する実験的研究 教育・ 社会心理学研究, 4, 115-127.

Peterson, M.F. 1982 The problem domain of member integration. (In) Armandi, B., Barbera, J., \& Berkman, H. (Eds.) Organizational 
Behavior: Classical and contemporary readings. Dubuque, Iowa: Kendall/Hunt. Pp.50-58.

坂元慶行・石黒真木夫 - 北川源四郎 1983 情報量統計 学 共立出版

Steers, R. M. 1975 Problems in the measurement of organizational effectiveness. Administrative Science Quarterly, 20, 546-548.

Steiner, I. D. 1972 Group process and productivity. New York: Academic Press.

Turner, R. H. 1976 Earthquake prediction and public policy: Distillation from a national academy of science report. Mass Emer- gencies, 1, 179-202.

矢守克也・三隅二不二・渥美公秀 1986 自然災害時に おける住民の対応に関する実証的研究（II）一長 野市地附山地滑り災害 (1985.7.26) の事例一全 体概要 (2) 第27回日本社会心理学会・第34回 日本グループダイナミックス学会合同大会発表論 文集, 77-78.

吉田民人 1963 集団系のモデル構成一機能的系理論の 骨子一社会学評論, 14(2), 42-73.

Zander, A. 1982 Making groups effective. San Francisco: Jossey-Bass.

-1987年 9 月14日 受稿, 1988年 6 月18日 受理一

\title{
THE EFFECTS OF LEADERSHIP BEHAVIOR IN THE NORMAL TIME ON FOLLOWER'S COPING BEHAVIOR WHEN EMERGENCY OCCURRED: AN EXPERIMENTAL STUDY
}

\author{
KATSUYA YAMORI JyUJI MisumI \\ Osaka University Nara University
}

\section{ABSTRACT}

The purpose of the present study was to investigate the effect of leadership behavior in the normal time on both follower's performance in the normal time (productivity) and follower's coping behavior when emergency occurred.

In the experiment, a subject was assigned a task of checking the column of holes punched on a card, which was subsequently input to a computer by a co-worker, a confederate, working beside him/her. The number of cards processed by a subject was a measure of productivity, while coping behavior was measured by a subject's response to an alarm bell of the co-worker's computer that was unexpectedly introduced while he/she was left alone in the laboratory.

Leader's behavior was manipulated based on Misumi's Performance (P)-Maintenance (M) theory. In the present study, a combination of
P-behavior emphasizing group goal achievement $\left(\mathrm{P}_{2}\right)$ and $\mathrm{M}$-behavior facilitating group solidarity $\left(\mathrm{M}_{2}\right)$ were examined in addition to a combination of $\mathrm{P}$-behavior emphasizing individual productivity $\left(P_{1}\right)$ and M-behavior reducing follower's tension $\left(\mathrm{M}_{1}\right)$.

The results were as following.

1. A combined $\mathrm{P}_{2}$ and $\mathrm{M}_{2}$ was found the most effective concerning not only productivity but also coping behavior (quick response to an alarm bell). It was mediated by follower's strong motivation for achieving group goal under this condition.

2. Leadership behavior in the normal time affected not only follower's productivity in the normal time but also follower's coping behavior when emergency occurred. This finding seemed relevant to crisis situation in which normalcy bias may disturb a quick response to a sign of danger.

Key words: coping behavior, leadership, group goal, group solidarity, normalcy bias, emergency 